\title{
TINJAUAN KUAT TEKAN BETON DENGAN MENGGUNAKAN SERAT BENDRAT SEBAGAI BAHAN TAMBAH
}

\author{
Hermansyah $^{1)}$, Moh Ihsan Sibgotuloh ${ }^{2)}$ \\ 1) Program Studi Teknik Sipil, Fakultas Teknik, Universitas Teknologi Sumbawa \\ 2) Program Studi Teknik Sipil, Fakultas Teknik, Universitas Teknologi Sumbawa \\ email: ${ }^{1)}$ hermansyah@uts.com, ${ }^{2)}$ mohihsansibgotuloh@gmail.com
}

\begin{abstract}
Abstrak
Meluasnya penggunaan konstruksi beton dan meningkatnya skala pembangunan maka kebutuhan akan material yang digunakan dalam campuran betonpun semakin tinggi. Salah satu inovasi dari beton adalah beton serat. Harapan ditambahkannya serat pada campuran beton seperti serat bendrat untuk meningkatkan nilai kuat tekan dari beton normal ( $0 \%$ ) yang sering digunakan, sehingga tujuan dari penelitian ini adalah untuk mengetahui pengaruh penambahan serat bendrat terhadap kemudahan pengerjaan (workability) dari campuran beton dan untuk mengetahui pengaruh penambahan serat bendrat terhadap kuat tekan beton. Pada penelitian ini serat yang digunakan adalah serat dari jenis bendrat dengan ukuran diameter $1 \mathrm{~mm}$ dan panjang $60 \mathrm{~mm}$. Variasi serat yang digunakan adalah 0\%, 0.4\%, 0.6\% dan 0.8\% berdasarkan berat beton segar. Campuran beton (mix design) menggunakan SNI 03-2834-2000 tentang perencanaan campuran beton dengan umur pengujian 28 hari. Hasil pengujiannya menunjukan bahwa pada nilai kuat tekan rata-rata terendah sebesar 12.291 MPa terjadi pada variasi $0 \%$ dan nilai kuat tekan rata-rata tertinggi sebesar 20.656 MPa pada variasi serat $0.8 \%$. Peningkatan tersebut disebabkan oleh sebaran serat yang merata pada beton yang dihasilkan, semakin tinggi variasi yang diberikan serat, maka sebara seratpun semakin baik, dari serat tersebut memberikan kontrisbusi yang cukup baik pada beton serat.
\end{abstract}

Kata Kunci : bendrat, bahan tambah, kuat tekan

\begin{abstract}
The more widespread use of concrete construction and the increasing scale of construction, the higher the demand for materials used in concrete mixes. One of the innovations of concrete is fiber concrete. Hope the addition of fiber in concrete mixes such as wire fiber to increase the compressive strength value of normal concrete that is often used, so the purpose of this study is to determine the effect of adding wire fiber to the ease of working (workability) of the concrete mixture and to determine the effect of adding wire fiber to concrete compressive strength. In this study, the fiber used is the type of wire fiber with a diameter of $1 \mathrm{~mm}$ and a length of $60 \mathrm{~mm}$. Fiber variations used are 0\%, 0.4\%, 0.6\% and 0.8\% based on the weight of fresh concrete. Concrete mix (mix design) using SNI 03-2834-2000 about concrete mix planning with a test life of 28 days. The test results showed that the lowest average compressive strength of 12,291 MPa occurred at 0\% variation and the highest average compressive strength value of 20,656 MPa at 0.8\% fiber variation. The increase is caused by the even distribution of fibers in the concrete produced, the higher the variation that is given by the fiber, the better the fiber spread, from these fibers provide a fairly good contribution to the fiber concrete.
\end{abstract}

Keywords: wire fiber, added material, compressive strength.

\section{Latar Belakang}

$\begin{array}{ccc} & \text { Perkembangan pembangunan disatu } \\ \text { negara bisa dilihat dari kemajuan dan }\end{array}$ kecanggihannya pada industri konstruksi. Indonesia adalah salah satu negara yang sedang mengalami tahap perkembangan yang cukup pesat dalam hal pembangunan infrastruktur khususnya di dunia konstruksi. Semakin meningkat pembangunan infrastruktur khususnya konstruksi disatu negara, semakin meningkat pula kebutuhan akan materialmaterial berkualitas tinggi terutama material pada konstruksi beton. Material konstruksi beton adalah salah satu material yang sangat sering digunakan dalam pembangunan infrastruktur baik di negara maju maupun di negara berkembang.

Pemakaian beton sebagai salah satu material sudah lama dikenal dan paling umum dipakai baik untuk struktur besar maupun kecil. Keunggulan beton dari material lainnya adalah kemampuannya dalam menahan gaya tekan yang tinggi, dapat dibentuk sesuai dengan kebutuhan konstruksi, ketahanan yang baik terhadap lingkungan sekitar serta proses pemeliharaannya yang lebih murah dan mudah. Semakin meluasnya penggunaan konstruksi beton dan meningkatnya skala pembangunan maka kebutuhan akan teknologi beton yang efektif dan efisien juga 
semakin tinggi. Salah satu teknologi beton yang saat ini dikembangkan adalah beton bermutu tinggi. Menurut Tjokrodimuljo (2012) beton bermutu tinggi dapat diartikan sebagai beton yang memiliki nilai kuat tekan (f'c) lebih dari $41 \mathrm{MPa}$. Secara struktural beton juga memiliki kelemahan yaitu kekuatan tarik yang rendah dan memiliki sifat getas, sehingga hal ini yang menjadikan sangat terbatas pada pemakaiannya. Kuat tarik yang rendah ini dapat diatasi pengaruhnya dengan pemakaian baja tulangan. Namun pada kenyataannya penambahan baja tulangan tidak memberikan hasil yang optimal. Retak-retak melintang halus atau yang sering disebut retak rambut masih sering timbul disekitar daerah tarik beton, sehingga dapat mempengaruhi keawetan bangunan. Untuk bangunan infrastruktur, sedapat mungkin kelemahan ini harus diantisipasi agar tidak meyebabkan kegagalan konstruksi.

Menurut Faizah (2017) pada penelitiannya, salah satu perbaikan didalam beton untuk meningkatkan kekuatannya adalah dengan penambahan serat kedalam adukannya yang biasa disebut dengan beton serat (fiber concrete). Ada beberapa jenis serat yang biasa dipakai sebagai bahan penambah yaitu serat baja (steel), kaca (glass), karbon (carbon) dan plastik (polypropylene). Selain bahan-bahan penambah diatas, ada juga bahan-bahan yang didapat dari alam untuk keperluan non structural seperti serabut kelapa, ijuk, tempurung kelapa, abu sekam dan serat tumbuhan-tumbuhan lainnya. Dalam ACI Comitte 544 dikatakan bahwa semua material yang terbuat dari baja/besi yang berbentuk fisik kecil/pipih dan panjang dapat dimanfaatkan sebagai serat pada beton sebagai bahan campuran.

Adapun tujuan dari penelitian ini adalah sebagai berikut:

Untuk mengetahui pengaruh penambahan serat bendratterhadap kemudahan pengerjaan (workability) dari campuran beton dan,

Untuk mengetahui pengaruh penambahan serat bendrat terhadap kuat tekan beton.

\section{Tinjauan Pustaka}

Pada penelitian yang dilakukan oleh Suprihatin (2013), penambahan serat berbentuk "W" dengan persentase 0\%, 0,25\%, 0,5\%, 0,75\% dan $1,0 \%$ dari berat total benda uji beton silinder dengan variasi panjang serat kawat bendrat $4 \mathrm{~cm}, 6$ $\mathrm{cm}$ dan $8 \mathrm{~cm}$ menghasilkan nilai kuat tekan yang meningkat. Dari semua variasi, kuat tekan maksimum beton terjadi pada penambahan serat kawat bendrat dengan persentase sebesar 0,75\% dan panjang $8 \mathrm{~cm}$. Kuat tekan yang didapatkan adalah sebesar 26,03 MPa. Ditinjau dari beton normal, kuat tekan maksimum mengalami penambahan kuat tekan sebesar 36,37\%.

Menurut Foermansah (2013), penambahan serat berupa kawat bendrat dengan bentuk " $Z$ " dengan variasi panjang serat $8 \mathrm{~cm}$ dan pesentase serat $0,5 \%$ dari berat benda uji telah mencapai kuat tekan maksimum yaitu sebesar 24,522 $\mathrm{MPa}$. Hal tersebut menunjukan terjadi peningkatan kuat tekan dari variasi normal sebesar $24,397 \%$. Beton normal sendiri memiliki kuat tekan sebesar 19,712 MPa.

Kuat tekan beton adalah besarnya beban per satuan luas, yang menyebabkan benda uji beton hancur bila dibebani dengan gaya tekan tertentu, yang dihasilkan oleh mesin tekan (SNI 1974: 2011)

\section{Metodologi Penelitian}

Adapun penelitian ini dilakukan di Laboratorium PUPR kabupaten Sumbawa dan PT. Bunga Raya Lesatari. Untuk memperjelas dari alur penelitian maka dibuatlah gambar ang ditampilkan oleh Gambar 1.

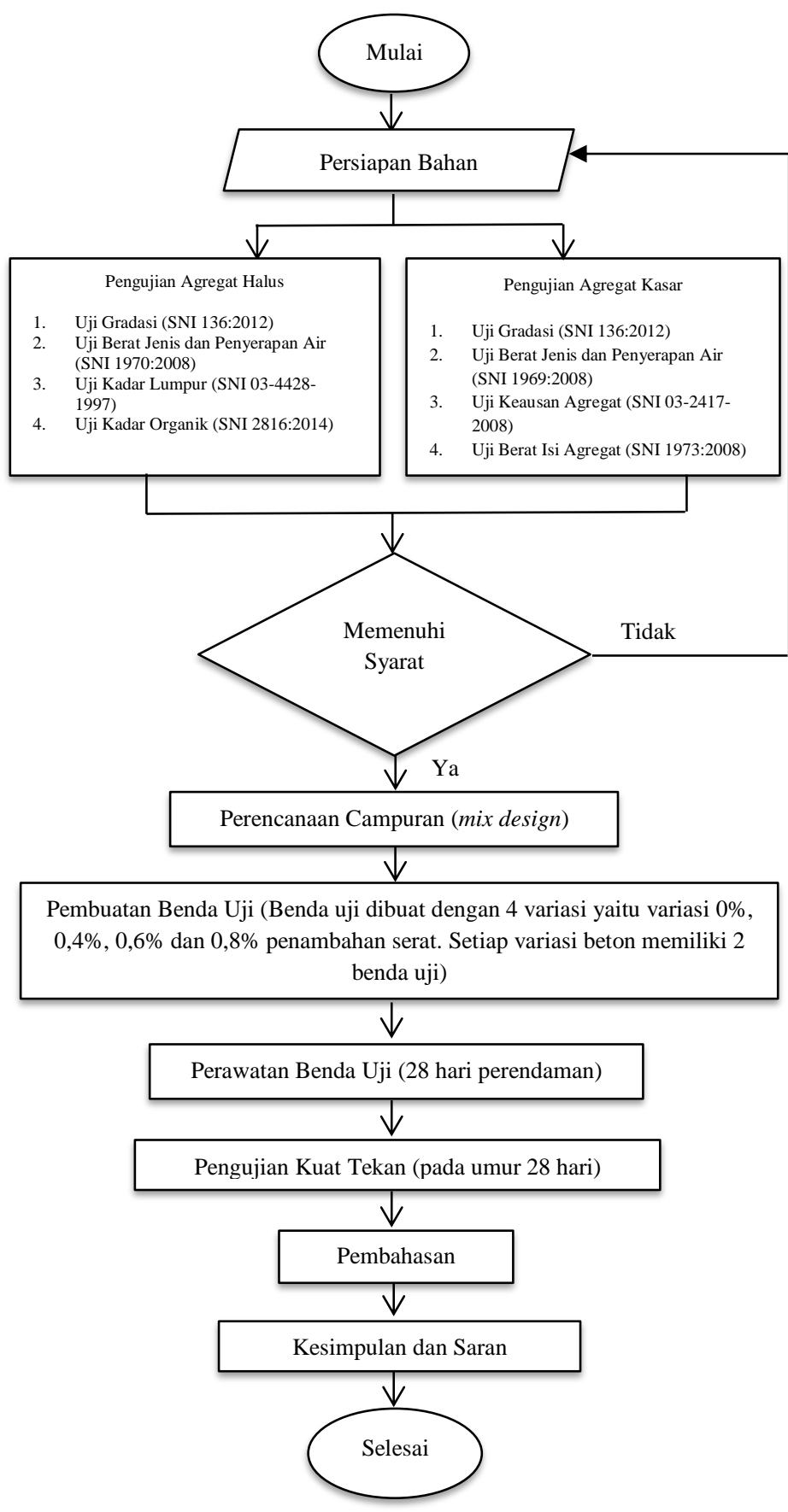




\section{Bahan}

Bahan-bahan dasar beton yaitu semen PPC merek tiga roda, air, pasir, batu pecah ukuran maksimal $20 \mathrm{~mm}$ dan juga bahan tambah berupa serat bendrat. Selain bahan, alat pencetakan yang digunakan adalah silinder berukuran $150 \mathrm{~mm}$ x 300 mm sebanyak 2 buah pervariasi.

\section{Pengujian}

Pengujian kuat tekan dilakukan untuk mengetahui kemampuan beton yang dihasilkan dalam menerima beban pada pengujian umur 28 hari.

\section{Analisis}

Setelah didapatkan hasil penelitian, selanjutnya data tersebut diolah dan dianalisis nilai kuat tekan beton dan hubungan variasi penambahan serat bendratdengan kuat tekan beton. Pada pengumpulan data yang akan dianalisis dan diambil adalah nilai rata-rata dari setiap variasi nilai slump dan kuat tekan beton hingga hubungan ang lainnya.

\section{Hasil dan Pembahasan}

\section{Uji Gradasi Agregat Halus}

Pengujian gradasi agregat halus dilakukan supaya dapat diketahui zonasi agregatnya.. Sehingga dengan mengetahui zonasi agregat kita akan mengetahui klasifikasi dan jenis agregat yang akan kita digunakan sebagai bahan pembuatan beton. Secara umum klasifikasinya adalah pasir kasar, pasir agak kasar, pasir agak halus dan terakhir pasir halus. Dari keempat klasifikasi tersebut bisa diketahui jenis pasirnya dari zonasi pasir setelah dilakukan pengujian gradasi. Agregat yang digunakan untuk pengujian terdiri dari dua sampel dengan berat pasir masing-masing 500 gram. Data yang diambil dari pengujian gradasi yaitu berat tertahan dari setiap ukuran saringan, persentase tertahan dan lolos dari setiap ukuran saringan. Setelah nilai persentase lolos saringan dari kedua sampel didapatkan, kemudian dirataratakan. Diharapkan dari pengujian gradasi ini pasir yang menjadi sampel pengujian masuk kedalam zona satu (pasir kasar) atau zona dua (pasir agak kasar) karena tekstur dari pasir zona satu/zona dua memiliki tingkat butiran yang kasar dan butirannya cenderung heterogen. Butiran pasir yang heterogen akan sangat bagus untuk menjadi bahan penyusun beton karena dengan heterogennya butiran pasir, memenimalisir ruang-ruang atau rongga pada beton yang mempengaruhi kuat tekan beton dan keawetan dari betonnya sendiri. Untuk lebih jelas bisa dilihat pada Tabel.1, Tabel.2 dan Tabel.3.
Tabel.1 Gradasi Agregat Halus Sampel I

\begin{tabular}{|c|c|c|c|c|}
\hline \multicolumn{2}{|c|}{$\begin{array}{c}\text { Ukuran } \\
\text { Saringan }\end{array}$} & \multirow{2}{*}{$\begin{array}{c}\text { Jumlah Berat } \\
\text { Tertahan } \\
\text { (Gram) }\end{array}$} & \multicolumn{2}{|c|}{ Jumlah Persen } \\
\hline ASTM & $\mathrm{mm}$ & & Tertahan & Lolos \\
\hline \#4 & 4,75 & 17,5 & 3,5 & 96,5 \\
\hline \#8 & 2,38 & 61,5 & 12,3 & 87,7 \\
\hline \#16 & 1,18 & 121,5 & 24,3 & 75,7 \\
\hline \#30 & 0,60 & 247,5 & 49,5 & 50,5 \\
\hline \#50 & 0,300 & 379,5 & 79,5 & 24,1 \\
\hline \#100 & 0,150 & 491,0 & 98,5 & 1,8 \\
\hline$\# 200$ & 0,075 & 495,5 & 99,1 & 0,9 \\
\hline
\end{tabular}

Dari Tabel.1 menampilkan terkait dengan nilai persentase tertahan dan persentase lolos agregat halus pada setiap ukuran saringan untuk sampel I.

Tabel.2 Gradasi Agregat Halus Sampel II

\begin{tabular}{ccccc}
\hline \multirow{2}{*}{$\begin{array}{c}\text { Ukuran } \\
\text { Saringan }\end{array}$} & \multirow{2}{*}{\begin{tabular}{c} 
Jumlah \\
Berat \\
\cline { 1 - 1 } Tertahan
\end{tabular}} & \multicolumn{2}{c}{ Jumlah Persen } \\
\cline { 1 - 1 } ASTM & mm & $\begin{array}{c}\text { Tertan } \\
\text { (Gram) }\end{array}$ & Tertahan & Lolos \\
\#4 & 4,75 & 17,5 & 3 & 97 \\
\#8 & 2,38 & 61,5 & 10,7 & 89,3 \\
\#16 & 1,18 & 121,5 & 20,6 & 79,3 \\
\#30 & 0,60 & 247,5 & 43,7 & 56,3 \\
\#50 & 0,300 & 379,5 & 72,5 & 275 \\
\#100 & 0,150 & 491,0 & 98 & 2 \\
\#200 & 0,075 & 495,5 & 99,1 & 0,9 \\
\hline
\end{tabular}

Pada Tabel.2 menjelaskan bahwa nilai persentase tertahan dan lolos agregat halus sampel II. Setelah kita kitahui persentse tertahan dan lolos dari kedua sampel, selanjutnya adalah mencari nilai persentase lolos rata-rata. Dari persentese lolos rata-rata itulah kita akan bisa mengetahui zona gradasi agregat halus yang diuji dengan cara membaca grafik gradasi agregat halus. Untuk lebih jelasnya bisa kita lihat lebih lanjut di Tabel.3.

Tabel.3 Rata-rata Persentase Lolos Saringan

\begin{tabular}{ccccc}
\hline \multicolumn{2}{c}{$\begin{array}{c}\text { Ukuran } \\
\text { Saringan }\end{array}$} & \multicolumn{2}{c}{ Jumlah Persen } & \% Lolos Rata- \\
\cline { 1 - 4 } ASTM & mm & $\begin{array}{c}\text { Lolos } \\
\text { Sampel I }\end{array}$ & $\begin{array}{c}\text { Lolos } \\
\text { Sampel II }\end{array}$ & \\
\#4 & 4,75 & 96,5 & 97 & 96,75 \\
\#8 & 2,38 & 87,7 & 89,3 & 88,5 \\
$\# \mathbf{\# 6}$ & 1,18 & 75,7 & 79,3 & 77,55 \\
\#30 & 0,60 & 50,5 & 56,3 & 53,4 \\
$\# \mathbf{\# 0}$ & 0,300 & 24,1 & 275 & 25,8 \\
\#100 & 0,150 & 1,8 & 2 & 1,9 \\
\hline
\end{tabular}


\#200 0,075

0,9

0,9

0,9

Dari Tabel.3 dihasilkan persentase lolos ratarata dari agregat halus yang telah diuji, selanjutnya untuk memudahkan pembacaan data hasil pengujian, data disajikan kembali dalam bentuk grafik. Selain data diata dari atbel diatas, grafik juga dilengkapi dengan batas bawah dan batas atas zonasi pasir agregat halus.

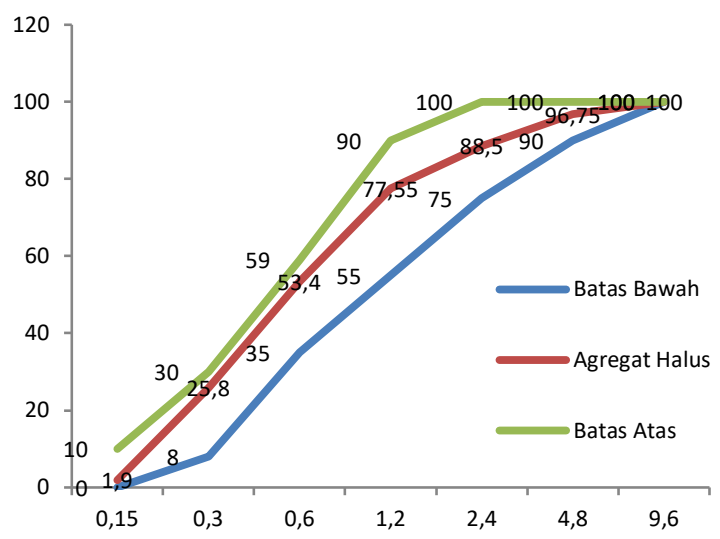

Gambar.2 Hasil Pengujian Gradasi Agregat Halus

Dari Gambar.2 menunjukan bahwa bahwa terjadi peningkatan persentase lolos seiring dengan makin besarnya ukuran saringan. Dan sebaliknya, persentase lolos saringan semakin kecil atau menurun seiring dengan kecilnya ukuran saringan dikarenakan semakin banyak agregat yang tertahan. Grafik persentase lolos ditunjukan oleh garis berwarna merah sedangkan, kedua garis yang mengapitnya adalah batas bawah zona II untuk garis warna biru dan batas atas zona II untuk garis berwarna hijau. Apabila garis grafik agregat halus hasil pengujian berada diantara garis batas bawah dan batas atas itu menunjukan pasir masuk kedalam zona tersebut.

\section{Pengujian Kadar Lumpur Agregat Halus}

Pengujian kadar lumpur dilakukan untuk mengetahui seberapa banyak kadar lumpur yang terkandung didalam agregat halus. Besar dan kecilnya kadar lumpur yang terdapat pada agregat halus berpengaruh terhadap kualitas bahan penyusun beton. Untuk mengetahui nilai kadar lumpur dibutuhkan data tinggi lumpur plus pasir dan data tinggi pasir. Perhitungan untuk nilai kadar lumpur menggunakan rumus sebagai berikut.

Perhitungan:

$$
\begin{gathered}
\text { Kadar Lumpur }=\frac{\mathrm{V}_{2}}{\mathrm{~V}_{1}+\mathrm{V}_{2}} \times 100 \% \\
=\frac{15}{510+15} \times 100 \%=2,9 \%
\end{gathered}
$$

Keterangan
$\mathrm{V}_{1}=$ tinggi pasir

$\mathrm{V}_{2}=($ tinggi pasir + lumpur $)-$ tinggi pasir

Berikut adalah tabel data hasil pengujian kadar lumpur yang didapatkan dari penelitian dilaboratorium dan hasil perhitungannya. Nilai kadar lumpur yang disyaratkan untuk pengujian yaitu maksimum 2\%. Dikarenakan nilai kadar lumpur di atas 2\% maka harus ada perlakukan khusus untuk pasir sebelum dilanjutkan kepengujian tahap berikutnya. Salah satu perlakuan khusus untuk pasir yang memiliki kadar lumpur diatas 2\% adalah dengan mencucinya. Diharapkan dengan proses pencucian tersebut, pasir menjadi bersih dan siap digunakan untuk tahap penelitian selanjutnya. Supaya lebih jelas, data dan hasil dari pengujian kadar lumpur bisa dilihat pada Tabel 4

Tabel.4 Uji Kadar Lumpur Agregat Halus

\begin{tabular}{cc}
\hline Keterangan & Nilai \\
\hline Tinggi Pasir & $510 \mathrm{~mm}$ \\
Tinggi Pasir + Lumpur & $525 \mathrm{~mm}$ \\
Tinggi Pasir + Lumpur) - Tinggi Pasir & $15 \mathrm{~mm}$ \\
Kadar Lumpur & $2,9 \%$ \\
\hline
\end{tabular}

Hasil dari nilai kadar lumpur yang tinggi diatas $2 \%$ yaitu $2,9 \%$ bisa dikarenakan faktor lokasi atau daerah pengambilan sampel pasir. Sampel pasir yang digunakan pada pengujian kadar lumpur ini diambil dari lokasi sungai Kanar, Sumbawa. Dimanapun tempatnya, apabila pasir diambil dari daerah sungai sudah tentu tercampur dengan lumpur sungai yang banyak. Sehingga faktor inilah yang menjadikan kadar lumpur pada sampel benda uji sangat tinggi dan mencapai $2,9 \%$.

\section{Pengujian Berat Jenis dan Penyerapan Agregat Halus}

Pengujian berat jenis dan penyerapan agregat halus sangat penting sekali dilakukan. Karena dengan data dan hasil dari pengujian berat jenis dan agregat halus ini didapatkan nilai berat jenis. Nilai berat jenis yang didapat akan berpengaruh sekali terhadap nilai berat jenis relatif agregat. Sedangkan nilai berat jenis relatif agregat akan mempengaruhi terhadap perencanaan campuran beton atau yang biasa disebut dengan mix design. Berat jenis agregat halus pengujian yaitu menggunakan alat piknometer, timbangan dan oven. Dari pengujian tersebut didapatkanlah data-data yang diperlukan, sehingga dari data-data tersebut bisa langsung dilakukan perhitungan sesuai dengan rumus. Berikut adalah data-data yang didapatkan dari penelitian. 
oven. Dari pengujian tersebut didapatkanlah datadata yang diperlukan, sehingga dari data-data tersebut bisa langsung dilakukan perhitungan sesuai dengan rumus. Berikut adalah data-data yang didapatkan dari penelitian.

Tabel.5 Uji Berat Jenis Agregat Halus

\begin{tabular}{cc}
\hline Keterangan & Berat Benda Uji (Gram) \\
\hline $\mathbf{B}_{\mathbf{t}}$ & 1001,0 \\
$\mathbf{B}$ & 711,5 \\
SSD & 500 \\
\hline
\end{tabular}

Dari Tabel.5 bisa diketahui bahwa nilai dari berat piknometer ditambah air dan benda uji sebesar 1001,0 gram. Kemudian dapat diketahui pula bahwa berat dari piknometer tambah air sebesar 711,5 gram. Yang terakhir adalah dapat diketahui bahwa berat benda uji kering permukaan jenuh sebesar 500 gram. Setelah ketiga data diatas ditemukan nilainya, tahap selanjutnya adalah mengaplikasikan data-data tersebut kedalam perhitungan untuk mencari berat jenis agregat halus. Perhitungan untuk mencari berat jenis dan penyerapan agregat halus memiliki rumus tersendiri. Adapun rumus untuk mencari nilai berat jenis kering permukaan jenuh (saturated surface dry specific gravity/SSD) yaitu:

Perhitungan:

$$
\begin{gathered}
\mathrm{BJ}_{\mathrm{SSD}}=\frac{500}{\mathrm{~B}+500-\mathrm{B}_{\mathrm{t}}} \\
\mathrm{BJ}_{\mathrm{SSD}}=\frac{500}{711,5+500-1001,0}=2,375
\end{gathered}
$$

Keterangan :

$\mathrm{B}=$ Berat piknometer berisi air (gr)

$\mathrm{B}_{\mathrm{t}}=$ Berat piknometer berisi benda uji dan air (gr)

$500=$ Berat benda uji kering permukaan jenuh/SSD (gr)

Dari hasil perhitungan denga rumus diatas, bisa kita simpulkan bahwa nilai berat jenis kering permukaan jenuh SSD pada agregat halus yang diuji memeliki nilai sebesar 2,375.

\section{Pengujian Berat Jenis dan Penyerapan Agregat Kasar}

Pengujian berat jenis dan penyerapan agregat kasar sangat penting sekali dilakukan. Karena dengan data dan hasil dari pengujian berat jenis dan penyerapan agregat kasar ini didapatkan nilai berat jenis. Nilai berat jenis yang didapat akan berpengaruh sekali terhadap nilai berat jenis relatif agregat. Sedangkan nilai berat jenis relatif agregat akan mempengaruhi terhadap perencanaan campuran beton atau yang biasa disebut dengan mix design. Berat jenis agregat kasar pengujiannya yaitu menggunakan alat timbangan, keranjang,bak dan
Tabel.6 Berat Jenis Agregat Kasar

\begin{tabular}{cccc}
\hline Keterangan & Sampel I & Sampel II & $\begin{array}{c}\text { Nilai Rata- } \\
\text { rata }\end{array}$ \\
\hline Ba & 612,9 & 540,8 & 576,85 \\
$\mathbf{B j}$ & 1035,7 & 915,2 & 975,45 \\
\hline
\end{tabular}

Dari Tabel.6 kita mengetahui data-data berat benda uji kering permukaan jenuh $\left(\mathrm{B}_{\mathrm{j}}\right)$, data berat benda uji kering permukaan jenuh didalam air $\left(\mathrm{B}_{\mathrm{a}}\right)$. Keempat data tersebut kemudian dicari nilai rataratanya. Nilai rata-rata dari keempat data tersebut bisa dilihat pada Tabel.5 paling kanan. Untuk mengetahui hasil nilai akhir dari berat jenis agregat kasar, diperlukan perhitungan khusus sesuai dengan rumusnya. Rumus yang digunakan untuk perhitungan sebagai berikut.

Rumus:

Keterangan

$$
\mathrm{BJ}_{\mathrm{SSD}}=\frac{\mathrm{B}_{\mathrm{J}}}{\mathrm{B}_{\mathrm{J}}-\mathrm{B}_{\mathrm{a}}}
$$

$\mathrm{BJ}_{\mathrm{SSD}}=$ Berat jenis kering permukaan jenuh.

$\mathrm{B}_{\mathrm{J}} \quad=$ Berat benda uji kering permukaan jenuh.

$\mathrm{B}_{\mathrm{a}}=$ Berat benda uji kering permukaan jenuh didalam air

Perhitungan:

$$
\mathrm{BJ}_{\mathrm{SSD}}=\frac{975,45}{975,45-576.85}=2,447
$$

Dari hasil perhitungan dengan rumus diatas, didapatkanlah nilai berat jenis kering permukaan jenuh agregat kasar yaitu sebesar 2,447.

\section{Uji Slump}

Pengujian nilai slump bertujuan untuk mengetahui workability atau kemudahan pengerjaan dari beton. Dari pengujian slump, didapatlah data-data nilai slump setiap pengadukan. Untuk lebih jelasnya bisa dilihat pada Tabel.7.

Tabel.7 Nilai Slump

\begin{tabular}{cc}
\hline Variasi Beton & Nilai Slump \\
\hline Normal & $5 \mathrm{~cm}$ \\
$\mathbf{0 , 4 \%}$ & $4 \mathrm{~cm}$ \\
$\mathbf{0 , 6 \%}$ & $3,7 \mathrm{~cm}$ \\
$\mathbf{0 , 8 \%}$ & $3,5 \mathrm{~cm}$ \\
\hline
\end{tabular}

Dari Tabel.7 dapat kita ketahui bahwa nilai slump untuk beton normal ( $0 \%$ ) adalah sebesar 5 $\mathrm{cm}$, untuk pengadukan beton kedua dengan 
penambahan serat $0,4 \%$ didapat nilai slump sebesar $40 \mathrm{~cm}$, untuk pengadukan ketiga dengan penembahan persentase serat $0,6 \%$ diadapat nilai slump sebesar $3,7 \mathrm{~cm}$ dan terakhir untuk pengadukan keempat dengan persentase penambahan serat $0,8 \%$ didapatkan nilai slump sebesar $3,5 \mathrm{~cm}$. Untuk mempermudah membaca data nilai slump dari setiap variasi beton, disajikan pula dalam bentuk grafik. Berikut adalah grafik nilai slump betton setiap variasi. Untuk lenih jelasnya bisa dilihat pada Gambar.3.

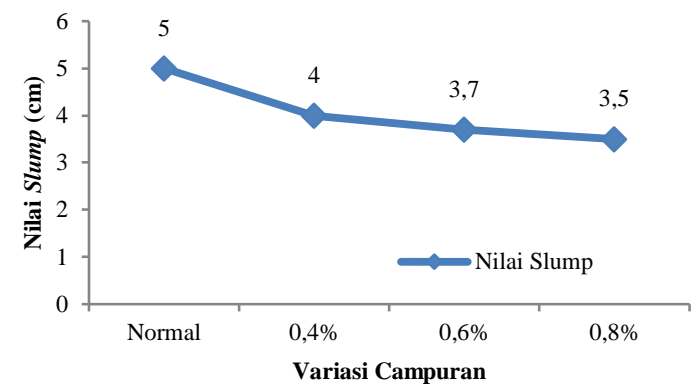

Gambar.3 Nilai Slump

\section{Perencanaan Campuran Beton}

Dalam perencanaan campuran beton dengan menggunakan metode SNI 7656-2012, maka didapatkan hasil sebagai berikut:

Tabel.8 Campuran Beton untuk $1 \mathrm{~m}^{3}$

\begin{tabular}{cccc}
\hline No & \multicolumn{1}{c}{ Uraian } & Nilai/Jenis & Satuan \\
\hline 1 & Nilai Kadar Air Bebas & 190 & $\mathrm{~kg} / \mathrm{m}^{3}$ \\
2 & Jumlah Semen & 283 & $\mathrm{~kg} / \mathrm{m}^{3}$ \\
3 & Kadar Agregat Halus & 674,7 & $\mathrm{~kg} / \mathrm{m}^{3}$ \\
4 & Kadar Agregat Kasar & 1055,3 & $\mathrm{~kg} / \mathrm{m}^{3}$ \\
& & 2265 & $\mathrm{~kg} / \mathrm{m}^{3}$ \\
\hline & Total & Dari hasil perhitungan & $\mathrm{m}^{3}, \mathrm{mak}^{2}$
\end{tabular}

didapatkan nilai campuran dari setiap variasi, untuk lebih jelas dapat dilihat pada Tabel 9.

Tabel.9 Campuran Beton untuk Setiap Variasi

\begin{tabular}{cccccc}
$\begin{array}{c}\text { Variasi } \\
(\%)\end{array}$ & $\begin{array}{c}\text { Ag. } \\
\text { Kasar } \\
(\mathbf{k g})\end{array}$ & $\begin{array}{c}\text { Ag. } \\
\text { Halus } \\
(\mathbf{k g})\end{array}$ & $\begin{array}{c}\text { Semen } \\
(\mathbf{k g})\end{array}$ & Air $(\mathbf{k g})$ & Serat \\
\hline $\mathbf{0}$ & 20,1352 & 12,8732 & 5,3996 & 3,6252 & 0 \\
$\mathbf{0 , 4}$ & 20,1352 & 12,8732 & 5,3996 & 3,6252 & 0,2012 \\
$\mathbf{0 , 6}$ & 20,1352 & 12,8732 & 5,3996 & 3,6252 & 0,2018 \\
& & & & & \\
$\mathbf{0 , 8}$ & 20,1352 & 12,8732 & 5,3996 & 3,6252 & 0,2024 \\
\hline
\end{tabular}

Copyright Jurnal JINTEKS

Dari Tabel.9 kita mengetahui bahwa perbedaan campuran terletak pada penambahan serat bendrat. Selain itu, semua material proporsinya sama karena yang dibuatpun jumlahnya sama.

\section{Berat Volume Beton}

Berat volume beton didapatkan dari hasil pembagian antara massa beton dengan volume silinder. Adapun untuk diameter dan tinggi silinder didapatkan dari hasil pengukuran menggunakan penggaris. Total data berat volume yaitu sebanyak 8. Dari 8 data ini setiap variasi beton dicari nilai rata-rata berat volumenya, supaya lebih jelas dan meyakinkan, data dari berat volume setiap sampel dan setiap variasi serta nilai rata-ratanya bisa dilihat pada Tabel.10. Tabel juga dilengkapi dengan data diameter dan dat tinggi silinder setiap sampel yang dibuat, sehingga informasi fisik benda uji yang dibuat lebih lengkap dan bisa dimanfaatkan untuk perhitungan pengujian berikutnya.

Tabel.10 Berat Volume Beton

\begin{tabular}{|c|c|c|c|c|}
\hline Keterangan & $\begin{array}{c}\text { Berat } \\
\text { Volume } \\
\left(\mathrm{kg} / \mathrm{m}^{3}\right)\end{array}$ & $\begin{array}{c}\text { Rata- } \\
\text { rata } \\
\text { Berat } \\
\text { Volume } \\
\left(\mathrm{kg} / \mathrm{m}^{3}\right.\end{array}$ & $\begin{array}{c}\text { Diameter } \\
\text { Silinder } \\
(\mathbf{m m})\end{array}$ & $\begin{array}{c}\text { Tinggi } \\
\text { Silinder } \\
\text { (mm) }\end{array}$ \\
\hline \multirow[t]{2}{*}{$0 \%$} & 2264 & 2272 & 151 & 300 \\
\hline & 2281 & & 150 & 300 \\
\hline \multirow[t]{2}{*}{$0,4 \%$} & 2280 & 2272 & 150 & 300 \\
\hline & 2264 & & 150 & 300 \\
\hline \multirow[t]{2}{*}{$0,6 \%$} & 2304 & 2279 & 150 & 300 \\
\hline & 2255 & & 151 & 300 \\
\hline \multirow[t]{2}{*}{$0,8 \%$} & 2236 & 2253 & 149 & 300 \\
\hline & 2270 & & 150 & 300 \\
\hline
\end{tabular}

Data berat volume didapatkan dari hasil perhitungan dengan menggunakan rumus berat volume sebagai berikut:

Perhitungan:

$$
\begin{gathered}
\text { Berat Volume }=\frac{12012}{\frac{1}{4} \times \pi \times \mathrm{D}^{2} \times \mathrm{t}} \\
=\frac{12012}{\frac{1}{4} \times \frac{22}{7} \times 0,15^{2} \times 0,3} \\
=2264 \mathrm{~kg} / \mathrm{m}^{3}
\end{gathered}
$$

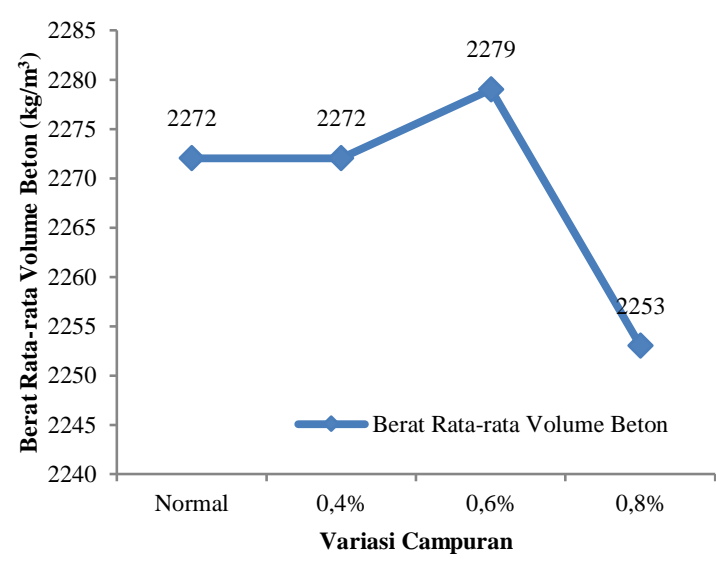


Gambar.4 Hubungan Berat Volume Beton dengan Variasi Serat

Pada Gambar.4 dihasilkan nilai berat rata-rata volume beton setiap variasi berbeda kecuali untuk variasi beton normal ( $0 \%$ ) dan beton dengan penambahan serat $0,4 \%$. Untuk beton normal ( $0 \%$ ) dan beton dengan tambahan serat $0,4 \%$ mendapatkan nilai rata-rata berat volume beton sebesar $2272 \mathrm{~kg} / \mathrm{m}^{3}$. Untuk beton dengan variasi penambahan serat bendrat $0,6 \%$ mendapatkan nilai rata-rata berat volume sebesar $2279 \mathrm{~kg} / \mathrm{m}^{3}$. Dan terakhir, beton dengan variasi penambahan serat bendrat $0,8 \%$ mendapatkan nilai rata-rata berat volume beton sebesar $2253 \mathrm{~kg} / \mathrm{m}^{3}$.

Penambahan serat diatas variasi $0,6 \%$ memberikan nilai berat volume yang menurun. Hal ini diakibatkan oleh penggumpalan serat yang menahan agregat kasar masuk kedalam ronggarongga, seharusnya rongga-rongga terisi oleh agregat sehingga itulah yang menyebabkan berat volume mengalami penurunan.

\section{Kuat Tekan Beton}

Nilai kuat tekan beton didapatkan dari nilai besarnya beban dibagi satuan luas. Nilai tersebut akan menentukan berhasil tidaknya kuat tekan beton yang direncanakan dengan hasil yang didapat setelah pengujian kuat tekan. Berikut adalah tabel nilai kuat tekan setiap sampel benda uji yang didapatkan dari hasil pengujian di laboratorium.

Uji pembebanan maksimal dilakukan sebanyak jumlah sampel benda yang akan diuji. Data dari pembebanan maksimal akan digunakan untuk mencari nilai kuat tekan beton dari setiap benda uji. Dalam penelitian yang dilakukan, data dari mesin uji kuat tekan dalam bentuk satuan $\mathrm{kN}$ (kilo newton) diubah kedalam satuan $\mathrm{N}$ (newton), kemudian dibagi luas alas silinder. Berikut adalah rumus perhitungan untuk mencari kuat tekan beton dan tabel data pembebanan maksimal yang diterima setiap benda uji :

Perhitungan:

$$
\begin{aligned}
\mathrm{f}^{\prime} \mathrm{c}= & \frac{\operatorname{Besar} \text { Beban }(\mathrm{N})}{\text { Luas Alas Silinder }\left(\mathrm{mm}^{2}\right)} \\
\mathrm{f}^{\prime} \mathrm{c}= & \frac{220000}{0,25 \times \frac{22}{7} \times 151^{2}} \\
& =12,291 \mathrm{MPa}
\end{aligned}
$$

Nilai besarnya beban pada perhitungan diatas masih dalam satuan $\mathrm{kN}$, sehingga perlu dikonversi kedalam satuan $\mathrm{N}$ untuk menghasilkan nilai kuat tekan yang disyaratkan. Cara perhitungan seperti ini berlaku untuk mencari nilai kuat tekan dari semua benda uji yang dibuat dalam penelitian. Untuk lebih jelasnya, nilai pembebanan maksimal dan nilai kuat tekan pada setiap sampel benda uji bisa dilihat pada Tabel.11.

Tabel.11 Nilai Kuat Tekan

\begin{tabular}{cccc}
\hline Keterangan & $\begin{array}{c}\text { Pembebanan } \\
\text { Maksimal } \\
(\mathrm{kN})\end{array}$ & $\begin{array}{c}\text { Kuat Tekan } \\
\text { Beton } \\
(\mathrm{MPa})\end{array}$ & $\begin{array}{c}\text { Rata-rata } \\
\text { Kuat Tekan } \\
\text { Beton } \\
(\mathrm{MPa})\end{array}$ \\
\hline Normal & 220 & 12,291 & 12,656 \\
$0,4 \%$ & 230 & 13,021 & \\
$0,6 \%$ & 245 & 13,871 & 13,725 \\
& 240 & 13,588 & \\
$0,8 \%$ & 270 & 15,321 & 14,644 \\
& 250 & 13,967 & \\
& 360 & 20,656 & 18,820 \\
\hline
\end{tabular}

Dari Tabel.11 bisa dilihat bahwa data yang tersaji adalah nilai pembebanan maksimal, nilai kuat tekan beton dan terakhir adalah nilai rata-rata kuat tekan beton. Nilai pembebanan maksimal didapatkan dari hasil peninjauan uji kuat tekan beton dilaboratorium dengan menggunakan alat yaitu CTM (Concrete Testing Machine), dari alat tersebut akan nampak jarum yang bergerak pada angka-angka dilayar mesin. Nilai pembebanan maksimal bisa diketahui ketika tepat jarum itu berhenti. Sedangkan untuk nilai kuat tekan, perlu didapatkan terlebih dahulu data nilai pemebebanan maksimal. Dari data pembebanan maksimal itu kemudian dibagi dengan luas silinder. Jangan sampai lupa untuk mengkonversi beban dan angka pembagi, supaya bisa didapatkan nilai kuat tekan beton yang disyaratakan. Untuk kolom paling kanan pada Tabel 11 diatas yaitu data nilai ratarata kuat tekan beton tiap variasi. Dari data tersebut bisa disimpulkan bahwa semakin besar persentase penambahan serat semakin tinggi pula kenaikan kuat tekan beton. Akan tetapi, kuat tekan dari 6 sampel yang ada pada tabel tidak memenuhi kuat tekan yang ditetapkan kecuali sampel 1 dengan penambahan serat $0,8 \%$. Nilai kuat tekannya yaitu sebesar 20,656 MPa.

\section{Hubungan Berat Volume dengan Nilai Kuat Tekan}

Hubungan antara berat volume dengan kuat tekan beton menjadi salah satu yang menarik untuk diperdalam dan dimunculkan datanya. Setelah data berat volume dan nilai kuat tekan didapatkan maka kedua data tersebut bisa kita sandingkan untuk mengukur hubungan dari kedua faktor tersebut. Untuk lebih jelasnya bisa dilihat pada Tabel.12. 
Tabel.12 Hubungan Berat Volume dengan Kuat Tekan Beton

\begin{tabular}{ccccc}
\hline Keterangan & $\begin{array}{c}\text { Berat } \\
\text { Volume } \\
\left(\mathrm{kg} / \mathrm{m}^{3}\right)\end{array}$ & $\begin{array}{c}\text { Rata- } \\
\text { rata } \\
\text { Berat } \\
\text { Volume } \\
\left(\mathrm{kg} / \mathrm{m}^{3}\right)\end{array}$ & $\begin{array}{c}\text { Kuat } \\
\text { Tekan } \\
\text { Beton } \\
(\mathrm{MPa})\end{array}$ & $\begin{array}{c}\text { Rata-rata } \\
\text { Kuat Tekan } \\
\text { Beton }(\mathrm{MPa})\end{array}$ \\
\hline \multirow{2}{*}{ Normal } & 2264 & 2272 & 12,291 & 12,656 \\
$0,4 \%$ & 2281 & & 13,021 & \\
$0,6 \%$ & 2280 & 2272 & 13,871 & 13,725 \\
& 2264 & & 13,588 & 14,644 \\
$0,8 \%$ & 2250 & 2279 & 13,967 & \\
& 2236 & & 20,656 & 18,820 \\
\hline
\end{tabular}

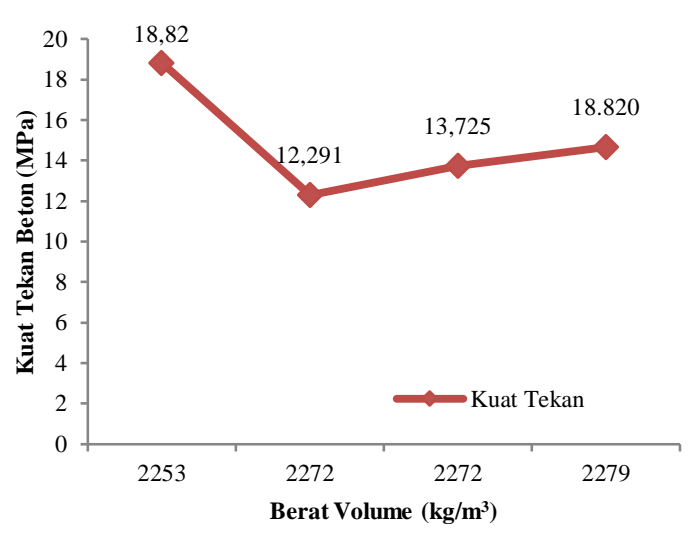

Gambar.5 Hubungan Berat dengan Kuat Tekan

Dari Gambar.5 dapat diketahui bahwa beton dengan volume rata-rata $2253 \mathrm{~kg} / \mathrm{m}^{3}$ memliki nilai kuat tekan tertinggi sebesar $18,820 \mathrm{MPa}$ bila dibandingkan dengan berat volume yang lain. Dengan penambahan serat yang cukup baik/merata sehingga menghasilkankan nilai kuat tekan yang cukup baik pula

\section{Hubungan Serat dengan Kuat Tekan}

Hubungan serat dan kuat tekan menjadi inti dari penelitian yang dilakukan. Bagaimanapun hasilnya, apakah kuat tekan beton menurun atau bahkan naik akan menjadi informasi untuk penelitian-penelitian selanjutnya. Pada penelitian yang dilakukan, penembahan serat bendratkedalam campuran beton menghasilkan kenaikan kuat tekan beton. Kenaikan kuat tekan beton terus meningkat seiring dengan terus ditambahnya persentase serat bendratsesuai dengan yang telah direncanakan.
Tabel.13 Hubungan Serat dengan Kuat Tekan

\begin{tabular}{cccc}
\hline Keterangan & $\begin{array}{c}\text { Kuat Tekan } \\
\text { Beton (MPa) }\end{array}$ & $\begin{array}{c}\text { Rata-rata } \\
\text { Kuat Tekan } \\
\text { Beton (MPa) }\end{array}$ & $\begin{array}{c}\text { Persentase } \\
\text { Kenaikan } \\
\text { Kuat } \\
\text { Tekan } \\
\text { Beton }(\%)\end{array}$ \\
\hline $\mathbf{0 \%}$ & 12,291 & 12,656 & 0 \\
$\mathbf{0 , 4 \%}$ & 13,021 & 13,725 & 7,8 \\
& 13,871 & & 13,5 \\
$\mathbf{0 , 6 \%}$ & 13,588 & 14,644 & \\
& 15,321 & & 32,7 \\
$\mathbf{0 , 8 \%}$ & 13,967 & 18,820 & \\
\hline
\end{tabular}

Untuk memudahkan dalam dalam pembacaan data hasil dari hubungan serat bendratdengan kuat tekan beton, penyajian data ditampilkan juga dalam bentuk grafik. Berikut adalah hubungan serat bendratdengan kuat tekan beton bisa dilihat pada Gambar.6.

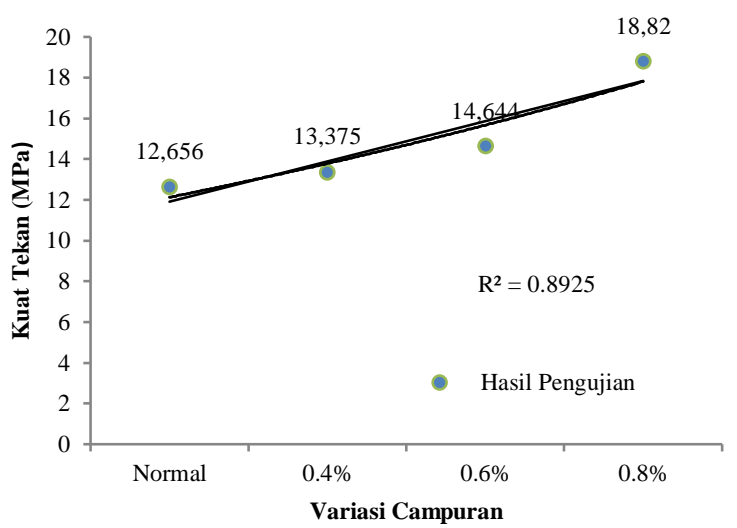

Gambar.6 Hubungan Serat dengan Kuat Tekan

Dari Gambar.6 bisa dilihat bahwa nilai kuat tekan beton mengalami peningkatan seiring dengan ditambahnya persentase serat sesuai dengan yang direncanakan. Peningkatan kuat tekan beton dari beton normal ( $0 \%$ ) ke variasi $0,4 \%$ sebesar $7.8 \%$. Peningkatan dari variasi normal ke variasi $0,6 \%$ sebesar $13,5 \%$ dan terakhir peningkatan kuat tekan dari variasi normal ke variasi $0,8 \%$ sebesar $32,7 \%$. Dari hubungan kuat tekan beton (f'c) dengan variasi penambahan serat bendrat menampilkan hasil kuat tekan beton yang semakin meningkat. Nilai maksimum persentase peningkatan kuat tekan beton yaitu dari beton dengan variasi normal ke variasi $0,8 \%$ yaitu sebanyak $32,7 \%$.

Peningkatan kuat tekan beton dari variasi $0 \%$, variasi $0,4 \%$, variasi $0,6 \%$ dan variasi $0,8 \%$ adalah sebesar $0 \%, 7,8 \%, 13,5 \%$ dan 32,7\%. Peningkatan tersebut disebabkan oleh sebaran serat yang merata pada beton yang dihasilkan, semakin tinggi variasi yang diberikan serat, maka sebaran seratpun semakin baik. Dari serat tersebut memberikan 
kontribusi yang cukup baik/memberikan nilai regangan yang baik .

\section{Kesimpulan dan Saran Kesimpulan}

Penambahan serat bendrat terhadap campuran beton sangat mempengaruhi terhadap kemudahan pengerjaan (workability). Terutama saat proses pencampuran bahan serat akan terjadi sedikit menggumpal ,sehingga mempersulit proses pengadukan beton. Hal ini diperkuat dengan hasil pengujian slump pada 4 varisi beton. Beton normal ( $0 \%$ ) memiliki nilai slump $5 \mathrm{~cm}$, beton dengan varisi serat $0,4 \%$ miliki nilai slump $4 \mathrm{~cm}$, beton dengan variasi serat $0,6 \%$ memiliki nilai slump 3,7 $\mathrm{cm}$ dan terakhir beton dengan variasi serat $0,8 \%$ memiliki nilai slump sebesar $3,5 \mathrm{~cm}$. Hasil tersebut memberikan kesimpulan bahwa semakin tinggi persentase penambahan serat bendrat terhadap beton maka semakin kecil nilai slump yang didapatkan sehingga pengerjaanpun semakin sulit.

Penambahan variasi persentase serat bendratsebanyak $0.4 \%, \quad 0.6 \%$ dan $0.8 \%$ berpengaruh terhadap penambahan kuat tekan beton. Semakin banyak persentase serat ditambahkan, semakin tinggi nilai kuat tekan beton. Pada beton normal ( $0 \%$ ) kuat tekan rata-rata didapatkan sebesar 12,656 $\mathrm{MPa}$, untuk beton dengan variasi serat $0,4 \%$ mendapatkan nilai ratarata kuat tekan $13,725 \mathrm{MPa}$, terjadi peningkatan kuat tekan sebesar 7,8\% dari beton normal ( $0 \%$ ). Untuk beton dengan variasi serat $0,6 \%$ memiliki nilai rata-rata kuat tekan sebesar 14,644 $\mathrm{MPa}$, terjadi peningkatan nilai kuat tekan sebesar 13,5\% dari beton normal ( $0 \%$ ). Untuk beton dengan variasi serat $0,8 \%$ memiliki nilai rata-rata kuat tekan sebesar $18,820 \mathrm{MPa}$, terjadi peningkatan nilai kuat tekan sebesar 32,7\% dari beton normal ( $0 \%$ ). Peningkatan tersebut disebabkan oleh sebaran serat yang merata pada beton yang dihasilkan, semakin tinggi variasi yang diberikan serat, maka sebaran seratpun semakin baik. Dari serat tersebut memberikan kontribusi yang cukup baik.

\section{Saran}

Perlu ditingkatkan ketelitian dalam perencanaan mix design dan proses pembuatan benda uji dari awal sampai selesai supaya mendapatkan kualitas beton yang tinggi. Semua pengujian material sebelum perencanaan dan pencampuran harus betul-betul dilakukan dengan teliti, sehingga data-data hasil pengujian tersebut bisa maksimal mendukung untuk perhitungan perencanaan beton yang akan dibuat, dan perlu menggunakan serat selain serat bendrat untuk mencari tahu nilai kuat tekan yang dihasilkan apakah lebih baik atau tidak.

\section{DAFTAR PUSTAKA}

[1] ACI Comitte (544. 1984). Guide For Specifing, Mixing, Placing and Finishing Still Fiber Reinforced Concrete. ACI Journal.

[2] ACI Comitte (544. 1988). Design Consideration For Steel Fiber Reinforced Concrete. ACI Journal

[3] Faizah (2017). Perbandingan Pengaruh Penambahan Serat Bendrat Lurus (Straight) dengan Serat Bendrat Berkait (Hooked) terhadap Prilaku Beton dengan Beban Tekan Berulang. Skripsi. Universitas Lampung.

[4] Foermansah (2013). Tinjauan Kuat Tekan dan Kuat Tarik Belah Beton Dengan Serat Kawat Bendrat Berbentuk Z Sebagai Bahan Tambah, Universitas Muhammadiyah Surakarta, Surakarta.

[5] Hidayat, M. (2017). Pengaruh Penambahan Serat bendratPada Beton Mutu Tinggi Terhadap Kapasitas Kuat Tekan dan Kuat Lentur. Skripsi. Universitas Lampung.

[6] Suprihatin (2013). Tinjauan Kuat Tekan dan Kuat Tarik Belah Beton dengan Serat bendratBerbentuk “ $W$ " sebagai bahan Tambah. Skripsi. Universitas Muhammadiyah Surakarta.

[7] Tjokrodimuljo, Kardiyono. (2009). Teknologi Beton. Yogyakarta. Biro Penerbit KMTS FT UGM.

[8] SNI (7656:20120). Tata Cara Pemilihan CampuranUntuk Benton Normal, Beton Berat dan Beton Massa. Badan Standarisasi Nasional

[9] SNI (2493:2011). Tata Cara Pembuatan dan Perawatan Benda Uji Beton di Laboratorium. Badan Standarisasi nasional.

[10] SNI (1974:2011). Cara Uji Kuat Tekan Beton dengan Benda Silinder. Badan Standarisasi Nasional. Jakarta

[11] SNI (1972:2008). Cara Uji Slump Beton. Badan Standarisasi Naisonal. Jakarta

[12] SNI (1970:2008). Cara Uji Berat Jenis dan Penyerapan Air Agregat Halus. Badan Standarisasi Nasional. Jakarta

[13] SNI (1969:2008). Cara Uji Berat Jenis dan Penyerapan Air Agregat Kasar. Badan Standarisasi Nasional. Jakarta

[14] SNI ASTM C (136:2012). Metode Analisis Saringan Agregat Halus dan Kasar. Badan Standarisasi Nasional. Jakarta 